\title{
Formulation of a training policy for the Library Assistants in Sri Lankan university libraries: a case study of the University of Peradeniya Library Network
}

\author{
Premarathne, Sunil ${ }^{1}$
}

\begin{abstract}
A university recognizes that its staff is fundamental to its success. Moreover a library is the life blood of a university. The quality of a library depends on its staff. If a library collection is not well organized and qualified trained staff is not employed, an efficient service cannot be expected. Staff training is a critical and challenging task. Library assistants form the largest staff category in any university library. They perform a wide variety of duties from counter operations to the acquisition, circulation of reading material, technical services and assistance with administration. There are 50 library assistants in the University of Peradeniya library network and they provide assistance to all categories of readers in the university of Peradeniya library network. Unfortunately, however, there is no comprehensive plan or policy for the training of library assistants. This survey was, therefore, conducted to collect baseline information required to formulate a comprehensive training policy for the library assistants in University of Peradeniya library network. A questionnaire was used to gather data from 50 library assistants while the response rate was $82 \%$ (41 library assistants responded). The findings of the survey revealed that the library assistants have not undergone appropriate inservice training. Whatever training they have had has been of an ad-hoc nature in the form of short courses and workshops. The areas of training needs of the library assistants are basic skills on information communication technology, handling of electronic information resources, database searching, communication skills, Tamil and English language proficiency and skills on library technical service. All of these do not appear to have been addressed broadly in existing training programmes. The findings of the survey have been carefully studied and the issues raised competently analysed and the data have been used to formulate a comprehensive policy for the training of library assistants. The policy provides a framework that supports and encourages the development of all the library assistants of the University of Peradeniya library network. The policy document covers equal opportunities of the training, identification of training needs in accordance with the requirements of the library ( library assistants training needs can be identified in a number of ways), and responsibilities of the trainees and senior staff of the library. Training policy also includes specific areas of the training requirement of the library assistants. The main areas are upgrading the knowledge in the overall background in the library or division, ability to perform all library activities to maintain a high level of services
\end{abstract}

\footnotetext{
${ }^{1}$ Senior Assistant Librarian, Faculty of Dental Sciences, University of Peradeniya, Sri Lanka.
} Email:sp12386@gmail.com 
to users, skills on counter operation, developing skills on library technical services such as acquisition procedure, cataloguing, conservation preservation, basic knowledge on book binding, knowledge on Information Communication Technology and communication skills.

Keywords: Library assistants, Training needs, Training, Human resources management,

\section{Introduction}

The prestige and integrity of an organization as well as the quality of service available to end users depend on the skill and dedication of the staff. The development of a highly skilled, dedicated staff requires planning, recruitment, training and motivation. "Staff training is a critical and challenging task that has to be identified with the determination of the future of many organizations" (Okemwa, 2000).

A university library is an organization that supports teaching, facilitates learning and caters to the research needs of the university community. The smooth running of a university library requires a well trained, efficient and dedicated staff. A comprehensive policy of training is, therefore essential to equip the staff with the knowledge and skills required to perform their duties efficiently.

The library assistants form the largest group of library employees who interact with the users in the University of Peradeniya library network. They perform a wide variety of services ranging from supporting the acquisition and circulation of materials to the maintenance of data bases and records, assist readers etc. Unfortunately there is no specific training policy for the library assistants for their career development. No study has been undertaken to analyse their training needs. Therefore this study was planned to answer the following specific questions:

1). What are the main areas to be considered in developing a training policy?

2). What are the training needs of the library assistants in the University of Peradeniya library network? 
Journal of the University Librarians Association of Sri Lanka, Vol.18, Issue 1, January 2014

3). What are the barriers to overcome in providing such training?

\section{Literature survey}

Training need is the gap between knowledge, skills and attitudes that the job demands and knowledge, skills and attitudes possessed by the trainees. The first requirement then is to assess this gap. A training need arises when an incumbent confronts a problem defying solution or when an actual situation of work behavior differs from desired condition in any aspect of organizational performance. It also exists when there is a change in objectives of the organization, or in the introduction of new programs, practices and techniques (Singh, 2000).

Training of library assistants is very necessary because they are involved in the day-to-day processing and organization of materials in the library. They also work with computer terminals or desks entering data, compiling bibliographic records, and helping patrons find library resources that require training because of change in library services (Bamidele, 2013)

Training is a process of practicing and learning again and again. Training is a continuous improvement in the quality of work performed. It will provide the staff with necessary knowledge, skills, abilities and attitude to perform their jobs. Training is to "bring a person to a desired state or standard of efficiency by instruction and practice". Training is a learning experience in that it seeks a relatively permanent change in an individual that will improve his or her ability to perform on the job. Training can involve the changing of skills, knowledge, attitudes, or social behavior. It may mean changing what employees know, how they work, their attitudes toward their work, or their interactions with their coworkers or with their supervisor. (Robbins, 1993)

Ohio University, job description of the senior library assistants describes that under general supervision, applies procedures, techniques, rules, and regulations within the limited scope of the job duties. (Ohio University job description, 2014) 
Journal of the University Librarians Association of Sri Lanka, Vol.18, Issue 1, January 2014

The Australian Library and Information Association (ALIA) describes the job of library assistants as the work of a member of a service team, assisting librarians and library technicians with library and office tasks and procedures. Typical tasks may include:

- $\quad$ Respond to enquiries and provide advice and assistance to library users.

- Work as part of a team in a library or information service environment.

- Show readers how to use information services e.g. electronic catalogues.

- Use electronic information management and cataloguing tools for data entry. (Australian Library Information Association ALIA, 2008)

\section{Library Assistants: duties and responsibilities}

Library assistants work as part of a team, supporting the day-to-day operations of libraries. The job title 'Library Assistant' usually applies to assisting users. Most of the library assistants are involved with the reader services or counter operations. Library assistants perform and/or supervise technical, paraprofessional duties typically under the direction of a librarian, in one or more functional areas in libraries and related units that are administered in accordance with the practices and techniques of professional librarianship; and perform related duties required. The duties of library assistants indicate that incumbents perform complex technical duties of a limited professional nature, in prescribed areas, under the direction of or in conjunction with librarians. These duties typically do not require the application of academic training in library principles and procedures at the full professional level. Library assistants are entrusted with a variety of duties, including: helping the library users to find the information they need, checking materials in and out, assisting enquiries by telephone, email, letter or fax, assisting to catalogue new materials, maintaining of databases and records, arranging of damaged materials for repair. Their duties vary from the main library to a branch library.

Library assistants are the officers who directly interact with the readers. Therefore they should have an adequate training to help them to deliver a quality and an effective customer service. The university user community is keen to obtain information on quick reference, 
Journal of the University Librarians Association of Sri Lanka, Vol.18, Issue 1, January 2014

information on reference tools and referral services. Hence library assistants in the reader services divisions should be equipped with adequate knowledge and skills on reference tools, further referral, and the ability to search databases and electronic information resources. Staff development refers to all policies, practices and procedures used to develop the knowledge, skills and competencies.

\section{Objectives of the study:}

The broad objective of this study was to collect information to formulate a policy document for the training of library assistants in the University of Peradeniya library network. The specific objectives are:

- To investigate the training needs of the library assistants.

- To identify the problems encountered by library assistants.

- To formulate training policy to address the issues raised.

\section{Methodology}

\section{Research Sample}

A total number of 50 library assistants in the University of Peradeniya library network were selected as a research population for the survey and the research sample was the same as the research population. Table no: 01 and 02 show the total number of library assistants in the library network and their recruited locations. 
Journal of the University Librarians Association of Sri Lanka, Vol.18, Issue 1, January 2014

Table 01: University of Peradeniya Library Network - Library staff in 2012

\begin{tabular}{|l|c|}
\hline \multicolumn{1}{|c|}{ Position } & $\begin{array}{l}\text { Number of staff } \\
\text { members }\end{array}$ \\
\hline Librarian & 01 \\
\hline Senior Assistant Librarians / Assistant Librarians & 19 \\
\hline $\begin{array}{l}\text { Library Assistants (Senior Staff Assistants / Staff Assistants / } \\
\text { Library Assistants Grade I,II,III) }\end{array}$ & $\mathbf{5 0}$ \\
\hline Technicians & 02 \\
\hline Attendants and Book Binders & 26 \\
\hline Driver & 01 \\
\hline Labourers & 18 \\
\hline Total & $\mathbf{1 1 7}$ \\
\hline
\end{tabular}

Source: Librarian's office statistics 2012

\section{Research Instrument}

The instrument of survey was the questionnaire. A carefully designed questionnaire comprising well formulated open and closed ended questions was mailed to 50 library assistants in the University of Peradeniya library network. The total number of 41 library assistants was responded and the response rate was $82 \%$. Since the questionnaire was administrated to all the library assistants in the university of Peradeniya library network, the research sample was the same as the research population. 
Journal of the University Librarians Association of Sri Lanka, Vol.18, Issue 1, January 2014

Table 02: Distributions of library assistants in University of Peradeniya Library Network

\begin{tabular}{|l|c|}
\hline \multicolumn{1}{|c|}{ Library } & $\begin{array}{l}\text { Number of Library } \\
\text { Assistants }\end{array}$ \\
\hline Main Library & 21 \\
\hline Science & 06 \\
\hline Agriculture & 05 \\
\hline Engineering & 06 \\
\hline Medical & 02 \\
\hline Veterinary Medicine and Animal Sciences & 02 \\
\hline Dental Sciences & 02 \\
\hline Allied Health Sciences & $\mathbf{5 0}$ \\
\hline Total & 06 \\
\hline Source: Librarians office statistics 2012 & 02 \\
\hline
\end{tabular}

Source: Librarians office statistics 2012

\section{Findings}

\section{Educational qualifications of the Library Assistants}

The General Certificate of Education (Ordinary Level) with 6 subjects at not more than 2 sittings including credit passes in five subjects is the basic minimum qualification for the recruitment of library assistants Grade III to the university library staff. Two of the credit passes must be in Sinhala or Tamil and English. According to the statistics shown in table no:03, it is revealed that $34(82 \%)$ employees have higher qualifications than the required basic qualifications. Only 07 staff members have GCE O/L qualification. On the other hand some of the library assistants have masters degree in Library and Information Science. It 
Journal of the University Librarians Association of Sri Lanka, Vol.18, Issue 1, January 2014 appears that the basic educational qualification of library assistants at recruitment level is very satisfactory and most have exceeded the basic requirements.

Table 03: Educational qualifications of Library Assistants

\begin{tabular}{|l|l|l|l|l|l|}
\hline \multicolumn{5}{|l|}{ Educational Qualifications } \\
\begin{tabular}{|l} 
GCE Ordinary \\
Level
\end{tabular} & $\begin{array}{l}\text { GCE } \\
\text { Advanced } \\
\text { Level }\end{array}$ & $\begin{array}{l}\text { Degree in } \\
\text { Library and } \\
\text { Information } \\
\text { Science }\end{array}$ & $\begin{array}{l}\text { Postgraduate } \\
\text { Diploma in } \\
\text { Library } \\
\text { science }\end{array}$ & $\begin{array}{l}\text { Total } \\
\text { Postgraduate } \\
\text { Degrees in } \\
\text { library science }\end{array}$ & 年 \\
\hline 07 & 24 & 07 & 01 & 02 & $\mathbf{4 1}$ \\
\hline $17 \%$ & $58.5 \%$ & $17 \%$ & $2.4 \%$ & $4.8 \%$ & $\mathbf{1 0 0 \%}$ \\
\hline
\end{tabular}

Table 04: Library and Information Science (LIS) qualifications

Library \& Information Science (LIS) qualifications

\begin{tabular}{|l|l|l|l|l|l|l|l|}
\hline $\begin{array}{l}\text { Master of } \\
\text { Social } \\
\text { Sciences in } \\
\text { LIS }\end{array}$ & $\begin{array}{l}\text { Associate } \\
\text { ship } \\
\text { (SLLA)* }\end{array}$ & $\begin{array}{l}\text { Diploma } \\
\text { (SLLA) }\end{array}$ & $\begin{array}{l}\text { Level - II } \\
\text { (SLLA) }\end{array}$ & $\begin{array}{l}\text { Level - I } \\
\text { (SLLA) }\end{array}$ & $\begin{array}{l}\text { First } \\
\text { Year } \\
\text { NILIS** }\end{array}$ & $\begin{array}{l}\text { Without } \\
\text { any LIS } \\
\text { qualific } \\
\text { ation }\end{array}$ & Total \\
\hline 02 & 04 & 08 & 06 & 12 & 01 & 08 & 41 \\
\hline $5 \%$ & $10 \%$ & $19 \%$ & $15 \%$ & $28 \%$ & $2 \%$ & $20 \%$ & $100 \%$ \\
\hline
\end{tabular}

(*SLLA $=$ Sri Lanka Library Association **NILIS=National Institute of Library and Information Science)

On the basis of data given in table no: 04 , it is noted that out of 41 respondents, there are two library assistants who have degrees in the field of library and information science. Other library assistants are at various stages in LIS qualifications such as associate level to 
Journal of the University Librarians Association of Sri Lanka, Vol.18, Issue 1, January 2014

Level- I of the SLLA. $20 \%$ of Library Assistants have not followed any LIS coursers. Thus

it is apparent that the majority of library assistants need further exposure to LIS training.

Table 05: Service Grades of Library Assistants

\begin{tabular}{|c|c|c|c|c|c|}
\hline \multicolumn{4}{|c|}{ Service Grades } & & \\
\hline $\begin{array}{l}\text { Senior Staff } \\
\text { Assistants }\end{array}$ & $\begin{array}{l}\text { Staff } \\
\text { Assistants }\end{array}$ & $\begin{array}{l}\text { Library } \\
\text { Assistants Gr.I }\end{array}$ & $\begin{array}{l}\text { Library Assistants } \\
\text { Gr.II }\end{array}$ & $\begin{array}{l}\text { Library } \\
\text { AssistantsGr. III }\end{array}$ & Total \\
\hline 14 & 02 & 14 & 04 & 07 & 41 \\
\hline $34 \%$ & $5 \%$ & $34 \%$ & $10 \%$ & $17 \%$ & $100 \%$ \\
\hline
\end{tabular}

The library assistants are divided in to 05 categories according to the recruitment procedure of the University Grant Commission (Table no: 05). The library assistants are recruited to the University library service at grade III level and are promoted to a higher grade after specified years of service. There is no policy or plan to train them to obtain further qualifications to get promotions and it is also not compulsory to follow any training.

Table 06: Skills for library operations

\begin{tabular}{|l|l|l|l|l|l|}
\hline Skills for Library operations & \multicolumn{5}{|l|}{} \\
\cline { 2 - 7 } & Good & Fair & Poor & Nil & Total \\
\hline $\begin{array}{l}\text { a). Library Acquisition } \\
\text { procedure }\end{array}$ & $12(29 \%)$ & $15(37 \%)$ & $09(21 \%)$ & $05(12 \%)$ & $\mathbf{4 1}$ \\
\hline $\begin{array}{l}\text { b). Cataloguing, data } \\
\text { entering }\end{array}$ & $23(56 \%)$ & $15(37 \%)$ & $02(5 \%)$ & $01 \quad(2 \%)$ & $\mathbf{4 1}$ \\
\hline $\begin{array}{l}\text { c). Conservation preservation } \\
\begin{array}{l}\text { d). Periodical ordering } \\
\text { maintaining }\end{array}\end{array}$ & -- & $11(26 \%)$ & $\begin{array}{l}14 \\
(34 \%)\end{array}$ & $16(39 \%)$ & $\mathbf{4 1}$ \\
\hline
\end{tabular}


Journal of the University Librarians Association of Sri Lanka, Vol.18, Issue 1, January 2014

Library assistants should ideally posses basic skills required for library operations. Findings of the survey revealed that of the required skills knowledge on cataloguing and data entering is at a satisfactory level. It was revealed that the other skills have to be enhanced. (Table no: 06)

Table 07: Skills on handling the electronic information resources

\begin{tabular}{|l|l|l|l|l|l|}
\hline $\begin{array}{l}\text { Skills on handling } \\
\text { the electronic } \\
\text { information } \\
\text { resources }\end{array}$ & Good & Fair & Poor & Nil & Total \\
\hline $\begin{array}{l}\text { a). Searching in } \\
\text { house databases }\end{array}$ & $29(70 \%)$ & $11(27 \%)$ & $01(3 \%)$ & -- & $\mathbf{4 1}$ \\
\hline $\begin{array}{l}\text { b). Using of CDs } \\
\text { and Audio/Videos } \\
\text { for educational } \\
\text { purposes }\end{array}$ & $20(48 \%)$ & $10(24 \%)$ & $03(7 \%)$ & $08(19 \%)$ & $\mathbf{4 1}$ \\
\hline $\begin{array}{l}\text { d). Searching of } \\
\text { scholarly articles in } \\
\text { the internet }\end{array}$ & $13(31 \%)$ & $20(48 \%)$ & $04(9 \%)$ & $04(9 \%)$ & $\mathbf{4 1}$ \\
\hline e). Using of E-mail & $21(51 \%)$ & $14(34 \%)$ & $03(7 \%)$ & $03(7 \%)$ & $\mathbf{4 1}$ \\
\hline f). Using Internet & $24(58 \%)$ & $12(29 \%)$ & $04(9 \%)$ & $01(2 \%)$ & $\mathbf{4 1}$ \\
\hline
\end{tabular}

It is becoming increasingly evident that library assistants require some knowledge of electronic information resources in order to cater for the needs of users. According to table no: 07 it appears that library assistants have satisfactory knowledge of the use of searching databases and Internet. They need further training in other fields such as searching of scholarly articles. 
Journal of the University Librarians Association of Sri Lanka, Vol.18, Issue 1, January 2014

Table 08: Satisfaction with previous training programmes

\begin{tabular}{|l|l|l|}
\hline $\begin{array}{l}\text { Satisfaction with the } \\
\text { previous training } \\
\text { programmes }\end{array}$ & Number & Percentage \\
\hline Very much satisfied & 06 & $15 \%$ \\
\hline Moderately satisfied & 11 & $27 \%$ \\
\hline Not satisfied at all & 22 & $53 \%$ \\
\hline Not answered & 02 & $5 \%$ \\
\hline Total & $\mathbf{4 1}$ & $\mathbf{1 0 0 \%}$ \\
\hline
\end{tabular}

Previous training programmes were very limited and most of them were of an ad hoc nature. Therefore the study was intended to ascertain the level of satisfaction of the participants who have participated in these programmes. It is very clear that the majority of library assistants are dissatisfied with the previous training programmes. It gives a clear picture from the data in table no: 08.

Table 09: Reasons for not attending the training

\begin{tabular}{|l|l|l|}
\hline \multicolumn{1}{|c|}{ Reasons for not attending the training } & Frequency & Percentages \\
\hline Non selection for training & 18 & $44 \%$ \\
\hline $\begin{array}{l}\text { Inability to leave work place due to lack of staff to } \\
\text { cover duties }\end{array}$ & 03 & $7.5 \%$ \\
\hline Personal dislike to attend any training & -- & -- \\
\hline $\begin{array}{l}\text { Inability to attend training because they are } \\
\text { conducted in faraway place. }\end{array}$ & 03 & $7.5 \%$ \\
\hline There was no training relevant to the job & 17 & $41 \%$ \\
\hline Total & $\mathbf{4 1}$ & $\mathbf{1 0 0}$ \\
\hline
\end{tabular}


Attendance at previous training programmes by the library assistants had been very low.

This study was intended to identify the reasons for poor attendance at training programmes.

According to table: 09 , there are $41 \%$ of respondents who felt that training was not relevant. $44 \%$ of the respondents stated that they had not been selected for training.

Table 10: Language Competency of the Library Assistants

\begin{tabular}{|cc|l|l|l|l|l|}
\hline \multirow{2}{*}{ Language Competency } & \multicolumn{5}{|l|}{} \\
\cline { 3 - 7 } & Good & Fair & Poor & Nil & Total \\
\hline Writing & & & & - & 41 \\
\hline & English & $21(51 \%)$ & $19(46 \%)$ & $01(03 \%)$ & -- & 41 \\
\hline Tamil & $02(05 \%)$ & $02(05 \%)$ & $05(12 \%)$ & $32(78 \%)$ & 41 \\
\hline Speaking & Sinhala & $39(95 \%)$ & $02(05 \%)$ & -- & -- & 41 \\
\hline & English & $20(49 \%)$ & $17(41 \%)$ & $04(10 \%)$ & -- & 41 \\
\hline Tamil & $02(05 \%)$ & $02(05 \%)$ & $06(15 \%)$ & $31(75 \%)$ & 41 \\
\hline
\end{tabular}

According to table no: 10, most of the library assistants are thorough in their mother tongue, especially the Sinhala language. Language competency in English (both writing and speaking) is considerably poor. Therefore, it appears that English language training is a timely significant factor with regard to the language training needs of library assistants. Also it was evident that language proficiency in Tamil is very poor. There is no proper language training procedure for them. This is another area which should be considered when formulating a training policy. 


\section{Discussion}

The study revealed that all the library assistants has had very limited training opportunities

for their career development. Most of the opportunities were ad hoc, short courses, and periodic workshops.

The library assistants do not have any efficiency bar examination and neither it is compulsory for them to follow any training for their promotions. They can achieve their promotions without any training as service is the only criterion for promotions. More than $45 \%$ of respondents answered that they are interested in obtaining knowledge and skills through training to improve their work performance. They also gave priority to the need to improve their professional knowledge in order to get their promotions.

Non-availability of appropriate training opportunities such as language and ICT skills and lack of encouragement for training and non availability of a training policy are also a severe setback for library assistants.

The survey revealed that most of the library assistants have a good knowledge in data entering and the basics of cataloguing. Knowledge in other areas such as library acquisition procedure, conservation and preservation, ordering and maintaining of periodicals, searching online journals, use of CDs and audio / videos for educational purposes, searching of scholarly articles in the internet, are fields where library assistants require adequate training. Knowledge on searching in house database is at a satisfactory level but knowledge on information communication technology (ICT) should be upgraded for them.

The required minimum qualification for library assistants grade III is GCE (O/L) examination with 6 subjects at not more than 2 sittings with credit passes in 5 subjects. Two of the credit passes must be in Sinhala or Tamil and English. According to the above statistics, it was revealed that educational qualifications of 34 employees are at a satisfactory level. In addition also there are postgraduate degree holders. 


\section{Conclusion and recommendations}

The survey revealed certain shortcomings in the existing training programmes. There are few training opportunities available for library assistants and most of them are also ad hoc. Furthermore there are no well organized continuous training programmes or a training policy for the library assistants. Staff training and development is vital in a library and therefore the study proposes the following recommendations. It is very essential to formulate a proper training policy for career development of the library assistants. The different fields of the trainings vary with each other. The main contents of the training policy which I have summarized in the appendix will be a guide to implement a better training in future.

Organize appropriate training programmes by the respective libraries. Training should provide staff with advice and guidance as to what is expected of them, and it should help them to cope with change. Training need analysis can be useful in providing staff with an opportunity to focus on their abilities and identify areas where they feel inadequate. In addition, the management can use the results of the exercise to identify gaps in knowledge skills, and it will help matching staff skills and knowledge on to roles and responsibilities either current or future. Encourage training organizations such as Sri Lanka Library Association (SLLA), National Institute for Library and Information Sciences (NILIS) to provide more appropriate training programmes according to the training needs of the library assistants.

The quality of a library depends on its staff. They are the key elements in the provision of information services. If quality output is the expectation, then the input should be the training of the human resources. 
Journal of the University Librarians Association of Sri Lanka, Vol.18, Issue 1, January 2014

\section{References:}

Australian Library and Information Association. (2008). Retrieved from http://archive.alia.org.au/education/qualifications/library.assistant.html.(Accessed on 25-01-2014)

Bamidele, I. A. (2013). Training of library assistants in academic libraries: a case study of Babcock university library, Nigeria. Retrieved from http://sgo.sagepub.com/ (Accessed on 20- 06-2014)

Buchanan, R. A. (2005). Library Assistant Training: Perceptions, Incentives, and Barriers The Journal of Academic Librarianship, 31(1), 421-431.

DeCenzo, D. A., Robbins, S. P. (1993). Personnel Human Resource Management (3 ${ }^{\text {rd }}$ ed). New Delhi: Prentice Hall

Fama, J., Ingrassia, B. (2009). Training Library Assistants for New Roles : University of Massachusetts Medical School Library Publications and Presentations. Paper 113. Retrieved from http://escholarship.umassmed.edu/lib_articles/113, (Accessed on 24.02.2013)

Garrod, P. (2001). Staff training and end user training issues within the hybrid library, Library Management, 22 (1/2), 30-36.

Irving, A. (1984). Education and training for library and information work. Library News, 5 (1-2), 29-36.

Nwali, L.O. (1992). Curriculum development for senior library assistants' course. Journal of Education for Library and Information Science, 33(2), 151-155.

Ohio University. (2014) .Ohio University job description: Classified positions. Retrieved from http://www.ohio.edu/hr/compensation/descriptions/classified.cfm (Accessed on 20-01-2014)

Okemwa, E.O. (2000). Training need of practicing professional librarians in the Kenya public University libraries: a critical analysis. Library Management, 21(5), 257-268

Singh, R. P. (2000). Management of training programmes. New Delhi: Anmol publication.

University of Peradeniya .(2011). Statistical handbook of University of Peradeniya, Retrieved from http://www.pdn.ac.lk/uop/about/Hand_Book/Hand_Book.html (Accessed on 21-12-2013) 
Journal of the University Librarians Association of Sri Lanka, Vol.18, Issue 1, January 2014

University Grant Commission .(2000). Circulars No: $761.26^{\text {th }}$ April. Retrieved from : http://www.ugc.ac.lk/policy/circulars/Circular761.htm, (Accessed on 10.09.2013)

University Grants Commission .(1994). Circulars No: 594.17 $7^{\text {th }}$ January. Retrieved from http://www.ugc.ac.lk/policy/circulars/548_700/Circular594Annex.htm (Accessed on 10.09 .2012 ) 
Appendix

\section{Summary of the Formulated Training Policy (A draft)}

The main objective of the above survey was to formulate a training policy for the library assistants. Therefore the draft of the training policy and main areas are summarized as follows:

\section{Scope of the training policy}

The library recognizes that the training and development is a continuing process for library assistants. Training is seen as a necessary investment in order to provide an excellent service by the library. Training is not a privilege to be granted but should be a professional development for the entire library staff. This policy applies to the library assistants. Staff development embraces all forms of development activities including personal study, elearning, internal \& external courses, workshops, orientation etc.

\section{Aims and objectives of the policy}

The main aim of the policy is to provide a framework of training that supports and encourages the development of all the library assistants of the University of Peradeniya library network.

\section{Specific objectives:}

- To provide the skills, knowledge and competencies they need to work and for their continuous development.

- To acquire and develop the relevant knowledge skills and competencies to enhance their performance in their current role and where they are involved in successive planning for their next role within the library.

- All the library assistants shall receive an appropriately organized local induction training as required. 
Journal of the University Librarians Association of Sri Lanka, Vol.18, Issue 1, January 2014

- To develop the skills that enable staff to respond effectively to the demands placed upon them by internal changes.

Identification of training needs is essential to determine the requirement of the library assistants. Besides the policy should highlight the responsibilities of the respective librarians, heads of the Divisions/Branch Librarians as well as the responsibilities of the trainees who matter most.

The mandatory training areas of the training policy can be considered as follows:

\section{1). Upgrading knowledge in Overall background at the library, division or branch:}

Knowledge of existing work processes and procedures.

Understanding of possible changes to workflow and/or systems that will improve services to users.

Ability to perform all library activities to maintain a high level of service to user.

\section{2). Skills on counter operation:}

Communicating with a diverse user population.

Communication with readers concerned efficiently and effectively.

Filling information needs through access to the collection or through referral.

Using appropriate media to communicate information.

Demonstrating knowledge of library collections and resources. 
3). Developing skills on library technical service:

\subsection{Information Communication Technology (ICT)}

Demonstrating knowledge of basic computer operations

Demonstrating a basic understanding of the role of technology in the creation, retrieval and delivery of library resources, functions and services.

Demonstrating basic skills in the use of computer and audio- visual equipment.

Demonstrating the ability to retrieve information from electronic and multimedia formats.

Demonstrating an understanding of the library's role and responsibility for introducing applications of technology.

\subsection{Acquisitions}

Demonstrating knowledge of the publishing industry and vendor markets from which libraries acquire material.

Establishing and applying effective procedures for preparation of documents. Verifying, ordering, receiving orders, resolving problems, and fund accounting.

\subsection{Cataloguing}

Understanding the importance of identifying and locating materials in a library with awareness of end-user demands.

Maintaining accurate online catalogs. Adhering to current regional and national cataloging standards and schemes.

\subsection{Knowledge on Binding and Preservation}

Applying appropriate methods and techniques for physical preservation, including repair and binding.

Anticipating the need for protection of library materials. 


\subsection{Communication Skills}

Providing accurate information in a clear and concise manner.

Excellent written and verbal communication skills.(English, Tamil Language for Sinhala speaking Library Assistants and English, Sinhala for Tamil speaking Library Assistants)

Ability to represent the library appropriately in outside forums.

Developing and maintaining appropriate public contacts.

Demonstrating solid decision making skills.

Demonstrating thoughtful and effective problem solving skills that produce results that have minimal negative impact on library operations

Ability to analyze and find solutions, negotiate successful outcomes with patrons or other staff in times of difficult situations. 